\title{
Jovem Guarda versus MPB: A construção midiática da guerra
}

\author{
"Jovem Guarda" versus "MPB": The media construction of war
}

\author{
Marcelo Garson \\ Programa de Pós-Graduação em Ciências Sociais da Universidade Federal de Juiz de Fora (PPGCSO-UFJF) , Juiz de Fora, MG, \\ Brasil. \\ ORCID: 0000-0001-8767-1875 \\ <garson.marcelo@gmail.com>
}

\author{
Como citar este artigo (How to cite this article): \\ GARSON, Marcelo. Jovem Guarda versus MPB: A construção midiática da guerra. Revista Famecos, Porto Alegre, \\ v. 25, n. 3, p. 1-21, setembro, outubro, novembro e dezembro de 2018: ID29728. \\ DOI: http://dx.doi.org/10.15448/1980-3729.2018.3.29728.
}

\section{RESUMO}

A década de 60 assistiu à reorganização das relações de poder na música popular brasileira, a partir da emergência de uma nova geração de artistas jovens. Se hoje são classificados em dois grandes grupos tidos como antagônicos, Jovem Guarda e MPB, trata-se, em larga medida, das consequências de uma "guerra" que se forjou naquela mesma década, tendo a televisão como palco privilegiado, mas também se desdobrando em revistas, jornais, cinema e rádio. Utilizando-se da análise do discurso de viés bourdiesiano, o estudo de algumas de suas "batalhas" destacadas, busca compreender de que forma essas disputas e tensões afetaram decisivamente as hierarquias da música popular dos anos 60 . Ao longo do texto, percebe-se que a divisão em grupos não é somente o resultado das diferenças inegáveis de repertório, classe social e inclinação ideológica dos protagonistas, mas antes é um resultado da "guerra" que através de estratégias discursivas instrumentalizou a separação e acabou por nublar uma série de trânsitos, encontros e demandas que MPB e Jovem Guarda experimentaram.

\begin{abstract}
The 1960s witnessed a reorganization of power relations within Brazilian popular music, caused by the emergence of a new generation of young artists. If nowadays they are classified in two major antagonistic groups - "Jovem Guarda" and "MPB" -, it is due, to a large extent, to a "war" forged during that decade, one that had television as center stage, but also spread through magazines, newspapers, cinema and radio. Using Boudieu's discourse analysis, we focus on some of the most famous "battles", with the objective to understand in which way those disputes and tensions have affected the hierarchies of Brazilian popular music in the 1960s. Throughout the text it has become apparent that such antagonism was not only result of undeniable differences in repertoire, class and ideological inclination, but was also enabled by discursive strategies, which have obfuscate a number of issues experienced by "MPB" and "Jovem Guarda".
\end{abstract}

Keywords: Brazilian popular music. Jovem Guarda. MPB.

Palavras-chave: Música popular. Jovem Guarda. MPB

\section{Introdução}

Durante os anos 60, a televisão estendeu seu alcance e iniciou a penetração nas mais diversas classes e localidades do Brasil, processo que se completaria na década seguinte. Aos poucos, se firmava um novo mediador social: espaço de negociação de valores, maneiras de ver, estar e agir no mundo, cujos efeitos foram sentidos mais rapidamente nos meios urbanos. No campo da música 
popular, a TV ocupou posição central antes reservada ao rádio, que passou a gravitar ao seu redor junto a demais veículos midiáticos. Prova disso é que todos os maiores vendedores de disco da segunda metade da década de 60 chegaram ao estrelato após consagração televisiva'. A gramática radiofônica fazia ainda sua presença, se expressando no repertório dos artistas e em seus trejeitos de palco, elementos que, no entanto, precisaram lidar com o componente visual cada vez mais pronunciado.

Como causa e efeito desse processo, uma nova geração de intérpretes jovens passaria a desfilar diariamente pelo visor da TV. Comandando musicais de grande audiência, participando de programas de entrevista e até de shows humorísticos, obtiveram grande visibilidade, através de discos, rádios, jornais, revistas de variedade, semanários televisivos, e até cinema.

Em pouco tempo, tornaram-se ídolos nacionais, modelos de reconhecimento, identificação e conduta. Esse processo reconfigurou as hierarquias de poder da música popular brasileira e os personagens que dele participaram são, ainda hoje, à grosso modo, identificados em dois grandes grupos, Jovem Guarda e MPB. Acreditamos que as fronteiras entre eles foram definidas, em boa parte, pela ação da televisão e das mídias que gravitavam ao seu redor.

De um lado, talhados pela tradição romântica massiva, pelo rock-balada norte americano e pela sonoridade e visual dos Beatles ${ }^{2}$, encontravam-se jovens egressos das classes populares com canções que falavam de namoros, festas e carros. Do outro, a MPB, "música popular brasileira”, uma instituição cultural em que diversas matrizes - samba urbano, ritmos regionais, Bossa Nova e jazz - eram relidas com vistas à politização de forma e conteúdo, tendo o jovem universitário de classe média como paradigma (Napolitano, 2010). Convivendo na mesma emissora, a TV Record, cada um dos segmentos respondia por um musical: O Fino da Bossa, comandado pela dupla Elis Regina e Jair Rodrigues e Jovem Guarda, a cargo de Roberto Carlos, Erasmo Carlos e Wanderléa. As atrações consistiam em números musicais estrelados por artistas convidados e pelos próprios apresentadores. Somados aos Festivais da Canção, os musicais tornaram-se a plataforma de projeção dos maiores vendedores de discos na segunda metade da década de 60, com destaque para Roberto Carlos e Chico Buarque. Apesar de diferenças estéticas, Jovem Guarda e MPB disputavam um

1 Dados de venda de disco do IBOPE estão disponíveis em: http://segall.ifch.unicamp.br/documentos_ digitalizados/ibope/ibope_opiniao_publica/ibope_opiniao_publica_opp/ibope_opiniao_publica_ opp_pd/.

2 O rock balada também se expressa no repertório dos Beatles, especialmente em seu início de carreira. 
mesmo mercado massivo, ausente de nichos de consumo bem definidos e também impregnado pela influência do rádio, que se expressava no material sonoro e nas performances televisivas dessa nova geração.

Mas as disputas de mercado agora adquiriam novo status simbólico. Quando a ditadura, instaurada em 64, passou a conduzir um processo de modernização autoritário e tecnocrático, a produção cultural, em especial a música, recebeu a tarefa de debater os destinos da nação que antes competia a partidos, comitês ou sindicatos, então cerceados. A dimensão política ficou, assim, evidente (Napolitano, 2010). Não é possível, no entanto, apreender o sentido dessa disputa sem analisar como ela foi agenciada pelos meios de comunicação. Utilizado em semanários de TV, jornais e demais mídias, "guerra" foi o termo especialmente recorrente, naquele momento, para descrever a relação supostamente antagônica entre Jovem Guarda e MPB. Ao examinar dois registros recentes de diferentes naturezas, - a abertura de um musical da Rede Globo e a biografia de Roberto Carlos -, percebemos que a noção de guerra ainda persiste como chave explicativa para compreender o panorama da música popular dos anos 60.

Boa noite, afaste o sofá que hoje é festa, e festa de arromba. Nos anos 60 a jovem Guarda tomou corpos, corações e mentes, espalhando pelo país uma alegria ingênua fora de tempo e lugar. Dançar o iê iê iê e namorar era tudo o que importava. Em 1965, nosso rei, Roberto Carlos, era ainda um príncipe quando anunciou nas telas da TV brasileira "É uma brasa, mora?". Foi o grito de guerra da Jovem Guarda, um movimento que uniu rebeldia e inocência. Rebeldia nos cabelos compridos e nos ritmos das canções, inocência nas letras ingênuas de namoros adolescentes. A Jovem Guarda deu uma nova voz à juventude ao som das guitarras que enlouqueciam as garotas e causavam calafrios aos pais de família e à ala mais conservadora da MPB. Embalados pelo sucesso na televisão, os ídolos do movimento ditavam a moda e o comportamento. Nunca se foi tão jovem quanto nos anos 60 (Som Brasil, Especial Jovem Guarda, TV Globo, 26 mai. 2012).

Quando Roberto Carlos explodiu, vivíamos de fato um tempo de guerra e de guerrilhas no campo da música popular brasileira. Um inflamado Geraldo Vandré declarava: "Temos de lutar pela música nacional e contra a invasão do mercado brasileiro pela canção estrangeira" (Araújo, 2006, p. 170).

A "passeata contra as guitarras elétricas", O Manifesto do lê-iê-iê contra a onda de inveja ou os épicos ataques de Elis Regina à Jovem Guarda são episódios 
midiáticos espetaculares que costumam ser elencados como exemplos incontestes da suposta guerra. Referendar essa ideia, no entanto, é aceitar a linguagem a partir da qual o fenômeno era narrado, e em grande parte continua a ser. Isso leva a corroborar a existência de dois segmentos artísticos com feições e estratégias de ação mutuamente excludentes. É justamente essa oposição que buscaremos questionar. "Guerra", neste texto, ganha o caráter de conceito nativo, ou seja, utilizado pelos próprios atores para dar sentido à sua realidade. Mediante o resgate dos registros de época - jornais, revistas, programas de televisão e filmes - a intenção é estudar como se construiu a narrativa da "guerra" e seus efeitos sobre as hierarquias da música popular dos anos 60. Para além das diferenças inegáveis de repertório, classe social e inclinação ideológica, o objetivo é dar conta dos códigos compartilhados, trânsitos, encontros e demandas que MPB e Jovem Guarda experimentaram. Nesse sentido, buscaremos desmistificar simples antagonismos, apostando em um retrato mais meticuloso das relações de poder então vigentes. $\mathrm{O}$ artigo inicia pelo resgate do conceito de representação, depois analisa como a televisão redesenhou o mapa da música popular brasileira, por fim reconstrói a narrativa da guerra através de episódios específicos.

\section{Guerra como representação}

Na bibliografia sobre música popular nos anos 60, nem todos os trabalhos corroboram a posição antagônica expressa nas duas últimas citações. Porém, dentre as pesquisas específicas sobre Jovem Guarda (Zimmerman, 2013; Pederiva, 2000) ou MPB (Napolitano, 2010; Ghezzi, 2011), o privilégio a um ou outro segmento acaba não dando conta do caráter relacional que os liga.

A constituição de ambos os grupos requer uma análise que reconheça sua gênese cruzada, já que emergiram no mesmo momento histórico e respondendo às mesmas transformações da música popular. A diferença está na forma da resposta, mas não tanto nas questões que necessitavam ser respondidas. Essas constituem um arsenal de problemáticas compartilhadas. Nem os trabalhos de cunho específico, nem aqueles de caráter panorâmico (Naves, 2010; Zan, 1997), nos ajudam nesse sentido. Exceção digna de nota, o trabalho de Enor Paiano (1994) mobiliza a noção de disputa simbólica para compreender o processo de legitimação artística da música popular nos anos 60 . Nesse processo, enxerga como o cruzamento da dimensão política e mercadológica reorganizaram suas relações de poder.

Segundo Marcos Napolitano (2011, p. 86), "a televisão, capitaneada pela TV Record, descobriu, ou melhor, inventou a 'moderna música popular brasileira' (MPB)". O mesmo pode ser dito da Jovem Guarda. No entanto, pouco se tem feito para compreender a inserção dos meios de comunicação no processo de 
emergência dos grupos. Atentar à centralidade dos meios é o nosso objetivo. Observando como a narrativa da guerra se plasmou em diversos suportes - TV, jornais, revistas, rádio e cinema - buscaremos compreender o papel das mídias na construção dos sentidos e hierarquias da música popular.

Acreditando, como Pierre Bourdieu (1990, p. 159), que "o mundo social pode ser dito e construído de diferentes maneiras, de acordo com diferentes princípios de visão e divisão", cabe investigar esses princípios. A disputa pelo sentido, portanto, é também uma disputa por poder. Trata-se de analisar "o que falar quer dizer" (Bourdieu,1996), ou seja, de que forma os relatos acionados pelos meios de comunicação constroem e naturalizam divisões sociais. Para tanto a noção de representação é fundamental. Encarada como a "produção de significado através da linguagem" (Hall, 1997, p. 16), interessa-nos investigar de que maneira a mídia constrói, através de práticas linguísticas, certos domínios do real. As representações são maneiras de classificar grupos e pessoas, assim fornecem esquemas interpretativos do mundo. No entanto, não devem ser encaradas enquanto formas mais ou menos fieis à realidade, mas sim como mecanismos que constroem a realidade no próprio ato de narrá-la. O poder das representações é, assim, o "poder de fazer grupos com palavras" (Bourdieu, 1990, p. 167), ou seja, de organizar, categorizar e rotular, que é a própria tarefa de dar existência e legitimidade a um grupo social. Interessa-nos, agora, investigar como as representações midiáticas da Jovem Guarda e MPB, bem como de seus respectivos artistas, foram fundamentais para reorganizar as relações de poder na música popular.

\section{Música popular moderna ou iê-iê-iê?}

A televisão foi essencial para aglutinar e dar forma ao que hoje se conhece por MPB e Jovem Guarda e que entre 65 e 68 era comumente chamado de "moderna música popular brasileira", ou somente "música popular moderna", e "iê-iê-iê". Essa estratégia de segmentação está bastante clara na forma como a TV Record, emissora que então tinha sob contrato a maioria dos cartazes da música popular, organizava os seus musicais.

Enquanto a chamada "velha guarda" ou "bossa velha" se reunia no programa Bossaudade, apresentado por Cyro Monteiro e Elizeth Cardoso, os cantores estreantes dividiam-se entre O Fino da Bossa e o Jovem Guarda. O circuito boêmio e universitário, de um lado, e a cultura de adoradores da música jovem, de outro, ganharam visibilidade pública ao serem encampados pela TV, tendo suas fronteiras completamente reconfiguradas. $\mathrm{O}$ que antes eram nichos de mercado que praticamente não se tocavam, a partir de 1965 passaram a estabelecer uma relação indissociável, ao compartilhar as mesmas estruturas de mercado e almejar 
a mesma audiência doméstica e televisiva. Nesse processo, a TV Record, e demais mídias que gravitavam ao seu redor, foram fundamentais para institucionalizar as divisões entre iê-iê-iê e música popular moderna, o que veio a construir o sentido de cada um desses nichos musicais. Para tanto, também contribuíam a mídia escrita e a indústria fonográfica. Mediante reportagens e material promocional, também reforçaram as fronteiras ao classificarem os novos ídolos em um ou outro grupo.

O rótulo iê-iê-iê - corruptela de "yeah, yeah, yeah", refrão de She Loves You, dos Beatles - popularizou-se com o sucesso da banda no Brasil. Eles deixariam claro que a música era somente uma fração do principal produto vendido pelo artista: sua imagem. Em agosto de 1965, sob o comando de Roberto Carlos, Wanderléa e Erasmo Carlos, estreava o Jovem Guarda, show dirigido ao público jovem e barulhento que se amontoava dentro e fora do teatro Record.

A marca distintiva da juventude estava nas canções, no cenário, nos gestos e nos adornos. Explorando intensamente a visualidade, as performances dos intérpretes não mais miravam o microfone dos rádios, mas sim o olho da câmera. Elas colocavam o corpo em evidência, um corpo ausente de marcas da idade, cujos contornos seriam largamente explorados em minissaias, decotes e blusas abertas, com tons chamativos e estampas pouco usuais. A influência da moda londrina ficava evidente, expressando-se, também, nas longas cabeleiras e demais acessórios, que ganhavam destaque na tela da TV e em ensaios fotográficos. No campo sonoro, misturavam-se influências dos Beatles, do rock and roll e rock balada norte-americanos, do pop italiano e da vasta tradição romântica que vinha do bolero e samba-canção, cujo tom trágico e fatalista era suavizado e encaixado no universo hedonista de festas, e namoros juvenis. Nos palcos do Jovem Guarda, as imagens de automóveis, elemento recorrente de sua simbologia, exaltavam o consumo e a velocidade. Enquanto isso, os artistas bolavam coreografias e gestos que se tornavam suas marcas visuais registradas, reconhecidas e imitadas pela audiência.

Um playboy apaixonado e solitário (Quero que vá tudo para o inferno), um jovem destemido que exaltava suas capacidades de conquistador (Pode vir quente que eu estou fervendo) ou uma moça que queria impedir o casamento de seu amado (Pare o Casamento) são alguns dos temas presentes na narrativa fragmentada de canções que abusavam de gírias, humor e efeitos sonoros.

Em pouco tempo, o show se tornava um fenômeno de audiência. Gravado em São Paulo, chegava em vídeo-tape ao Rio de Janeiro, Porto Alegre, Recife e Salvador. Estrelar em seus palcos poderia render convites para filmes, ensaios fotográficos e sessões de entrevista. Até uma linha de produtos chamada Calhambeque, composta de calças, minissaias, bolsas, camisetas, 
sapatos, botas e artigos escolares, foi licenciada. A representação dos intérpretes fazia-se no cruzamento de diversas linguagens que gravitavam ao redor da TV.

É notável a profusão de reportagens focadas em suas vidas íntimas. Ocupadas em revelar seus amores, rivalidades, relações com a família, mas também comidas preferidas e cortes de cabelo, revistas como a InTerValo ou Contigo borravam as fronteiras entre representação e realidade, encenando uma "performance pública da vida privada" (McDonnel, 2012, p. 70). Os artistas tornavam-se personagens de si mesmos.

Roberto Carlos era o Brasa, o bom moço interiorano, franzino, religioso, com ar ingênuo, mas muito batalhador, feito sob medida para agradar as mães: "Zunguinha [apelido de Roberto] de vez em quando mata saudade no colo da mãe, Dona Laura" (InTerValo, 8 mai. 1966, p. 5). Ele vinha do interior do Espírito Santo, havia tentado carreira como imitador de Elvis, depois se aventurado na Bossa Nova e, por fim, encontrado sua posição de destaque por meio da mistura entre música romântica e rock comercial.

Já Erasmo Carlos era o Tremendão: "Alto, 1,85m, forte e corpulento, 90 quilos, o Tremendão (...) é um dos mais destacados bonitões da TV. Erasmo é tranquilo. Seu temperamento, contudo, pode variar com rapidez(..) tanto pode chorar, como distribuir sopapos a granel. Simpático e inteligente, ele é autêntico" (InTerValo, 27 nov. 1966, p. 19). Carioca, suburbano e filho de mãe solteira, após uma série de trabalhos enfadonhos encontrou vocação para a música com Elvis Presley (Carlos, 2009), de quem herdou a inspiração para a imagem de jovem rebelde, avesso a formalidades e que não "levava desaforo para casa".

Por último, temos Wanderléa, a Ternurinha, também chamada Garota papofirme: delicada, vaidosa, mas ao mesmo tempo independente e ambiciosa. Vinda do interior de Minas Gerais, passou a infância em programas de calouros mirins, só podendo, no entanto, ascender à carreira profissional quando libertou-se da rígida tutela do pai libanês." [...] seu pai [...] tinha, sobre a vida artística, ideias que já eram tidas como antiquadas no tempo em que Maomé começava a escrever o alcorão. [seu pai] disse que em três meses ela desistiria: Wanderléa já está há 4 anos na carreira e diz que não sai nunca mais" (Vasconcelos, 1966).

Em cada papel brilhava a galeria arquetípica de heróis e vilões dos quadrinhos, filmes e novelas. A mídia se retroalimentava de seus próprios signos, revelando seu caráter intertextual. Por meio não só das matérias impressas, mas de letras de canções, entrevistas, filmes e ensaios fotográficos, os intérpretes ostentavam carrões, apartamentos, indumentária e joias. Seus estilos de vida tinham no consumo o campo de articulação privilegiado e no hedonismo e individualismo seus valores capitais. 
Figura 1 - Narrativa de vida como narrativa de consumo

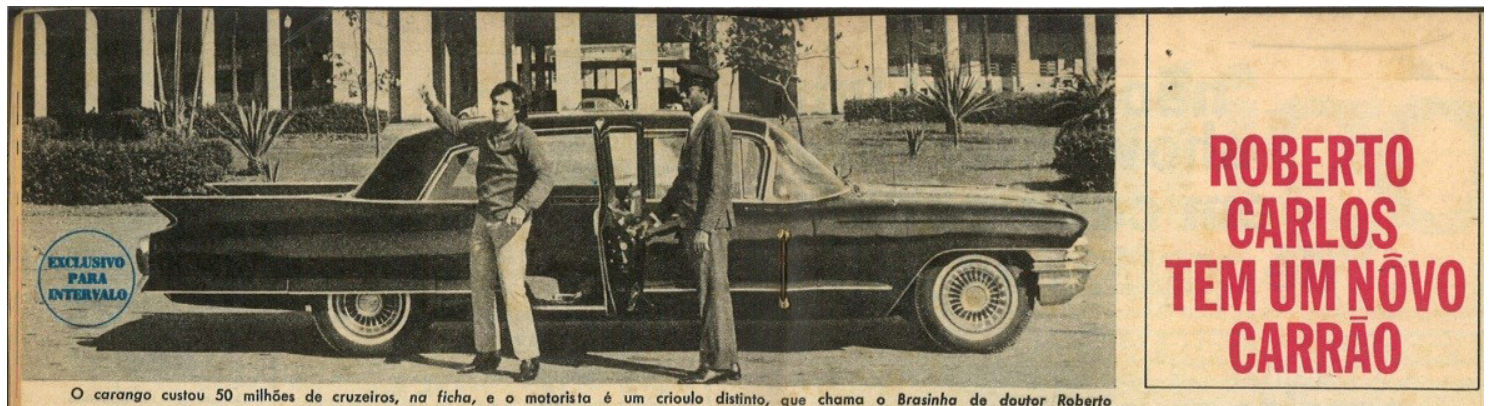

Fonte: InTerValo, 7 ago. 1966, p.35

A emergência da MPB, na época chamada "moderna música popular" ou "moderna música popular brasileira", possui suas particularidades, mas também teve que lidar com o mesmo regime de visualidade midiática. Por "moderna", "popular" e "brasileira" já temos pistas do que estava em jogo no cenário pós64 para a música popular. O legado bossa-novista, portanto "moderno", foi reconfigurado para dar conta das demandas por politização que incidiam no campo da música. Se a modernização implicava em abrir-se às influências estrangeiras, era necessário ponderar até que ponto a música continuava a expressar uma identidade nacional, ou seja, continuava a ser "brasileira", já que regida por mecanismos de estandardização e fórmulas de sucesso vindas de fora. Na tentativa de encontrar o "popular", a produção musical incorporou personagens (pescador, boiadeiro, trabalhador da construção civil) e ritmos (moda de viola, guarânias, samba, marcha) que aludiam às classes trabalhadoras, tanto rurais quanto urbanas. Relidas pelo legado expressivo da Bossa Nova, essas matrizes sonoras dariam origem às harmonias à base de folclore nordestino de Edu Lobo, ao canto exortativo de Elis Regina, ao samba urbano de Chico Buarque ou às canções épicas apoiadas na moda de viola e guarânia de Geraldo Vandré (Napolitano, 2010).

Quando o circuito de shows universitários e boêmios no eixo Rio-São Paulo é capturado pela lógica televisiva, muita coisa se altera. Os Festivais de Canção, inicialmente transmitidos pela TV Excelsior, e depois encampados pela Record, mudariam a natureza das apresentações. Baseados no festival italiano de San Remo, esses eventos consistiam em torneios em que, após diversas etapas, escolhia-se a melhor composição. De eliminatória em eliminatória, jornais, revistas e TV, conclamavam o público a tomar partido e formar torcidas criando um dos eventos de maior audiência na televisão dos anos 60 (Melo, 
2003). Nesse processo, três personagens merecem atenção especial: Elis Regina, Chico Buarque e Geraldo Vandré.

Quem conhecesse Elis em meados dos anos 60, não poderia imaginar tratar-se da outrora menina conhecida por sua meiguice e simpatia quando cantava boleros e sambas-canção no show de calouros mirins Clube do Guri. Também seria difícil crer que aos 16 anos, sorridente e de mãos para o alto, estreara em LP com Viva a Brotolândia, um apanhado de rocks balada produzido por Carlos Imperial, que almejava transformá-la na concorrente de Celly Campello, a então "rainha do rock".

\section{Figura 2 - Elis Regina, do Clube do Guri a Arrastão}

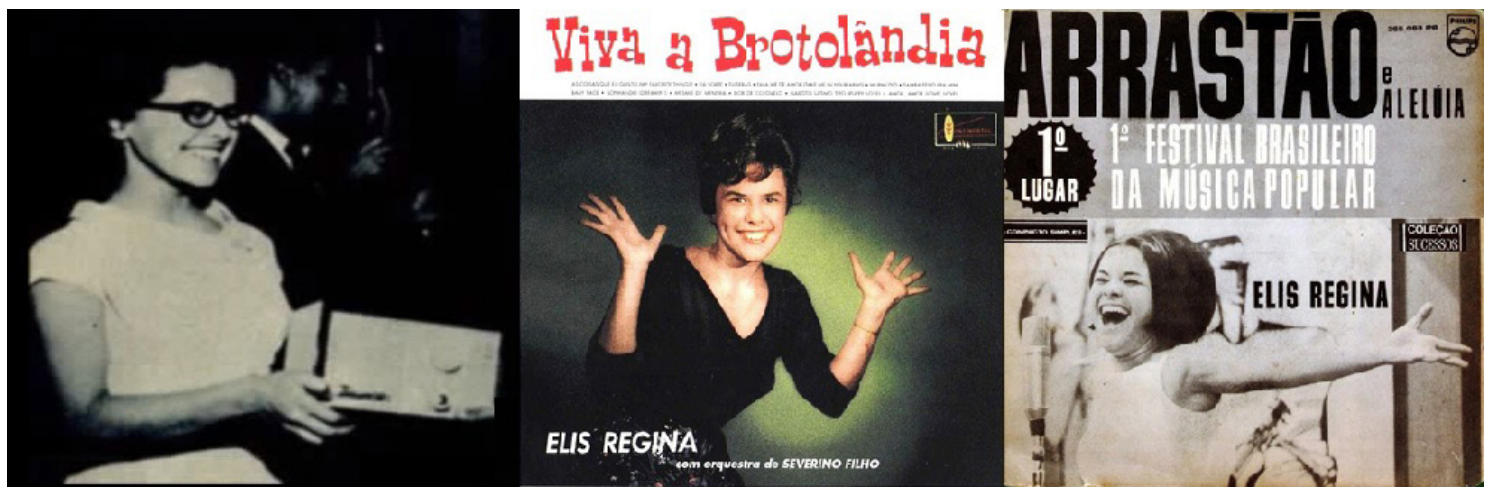

Fonte - Free Covers e Radionors

Na metade da década de 60, a inserção no circuito boêmio e universitário do Rio e de São Paulo mudariam sua carreira em definitivo. A fim de tomar a dianteira na superação da fase intimista e comedida da Bossa Nova, adotou uma performance sob medida para os grandes palcos e lentes televisivas. Enquanto rodava os braços para trás, utilizava truques de modulação vocal, construindo um espetáculo singular que se tornou sua marca registrada. Esse jogo de corpo não seria possível sem Lennie Dale, o coreografo nova iorquino saído da Broadway que ensinou Elis a se posicionar no palco (Mello, 2003).

A coreografia deu a Arrastão uma interpretação apoteótica (FIG 2) que lhe valeu a vitória no I Festival Nacional de Música Popular Brasileira da TV Excelsior. A canção, com letra de Vinicius de Morais e música de Edu Lobo, ao tematizar a labuta diária dos pescadores norteados pela imagem de suas amadas e fé em lemanjá, tornou-se o paradigma da composição engajada que almejava "encontrar o povo". Acabou, assim, firmando o modelo para edições subsequentes, que fizeram dos festivais a grande vitrine da MPB engajada (Napolitano, 2010, p. 117). A canção fez de "música de festival" um gênero que tinha por modelo "a temática com uma mensagem, como na letra de Vinicius [de Moraes]; a melodia contagiante, como na música de Edu Lobo; arranjo 
peculiar, que levantava a plateia, e a interpretação épica de Elis Regina" (Mello, 2003, p. 57). A característica teatral da performance remetia a Ângela Maria, grande ícone do rádio, cujo estilo interpretativo e eloquente foi a base para que Elis relesse e adaptasse a Bossa Nova à linguagem televisiva e ao grande público dos teatros, incitado a bater palmas e cantar junto.

Outro personagem que experimentou o estrelato após o sucesso nos Festivais da Canção é Chico Buarque. No ano seguinte à consagração de Elis no Festival da Excelsior, era a vez de Chico triunfar na TV Record quando ganhou o primeiro lugar no II Festival da Música Popular Brasileira, com A Banda. A canção conseguiu a proeza de unir mais 50 versos com linguagem simples, repleta de imagens do cotidiano, e que ainda resgatava um gênero popular, a marchinha, sob uma melodia que poderia ser facilmente cantarolada e assoviada.

Rotulado de "Arquiteto do Samba" (Contigo, set. 1966, p. 31) ou "General da Banda" (Manchete, 29 out. 1966, p. 15) pela mídia impressa, Chico, a partir de então, seria eleito como um dos grandes protagonistas no processo de renovação da música popular. No entanto, ainda que assumisse um projeto autoral ("Música pra mim também é estudo e projeto (...), mantenho-me em contato com os cantores visando à valorização do que é nosso, à valorização do samba", Contigo, ago. 1966, p. 33), não parecia disposto a ser rotulado nem como líder, nem como cantor engajado: "Minha música não é política. Não tem a pretensão [...] de mudar qualquer coisa, a não ser a própria música" (IVO, 1966, p. 106). Negar que sua música cumpria uma função tanto política, quanto mercadológica ("A profissionalização surgiu sem que eu tivesse esperado, e tudo faço pra que não quebre o meu sossego" (mesmo autor)) era uma maneira de reivindicar algum controle sobre sua representação pela via do ascetismo. No entanto, essa imagem de distanciamento era negociada nas próprias mídias visuais, portanto dentro do mercado.

Chico e Elis haviam percebido que "o povo" não estava somente nos tipos representados e interpelados em suas canções, mas, sobretudo encarnava-se na audiência massiva, doméstica e televisiva. É na revista mais representativa da lógica midiática e espetacular daquele momento, o popular semanário televisivo InTerValo, que encontramos uma reportagem que sintetizava os dilemas da MPB. Com o título Chico Buarque: Minha música fala com o povo e o subtítulo Meninão de olhos verdes imitava João Gilberto (FIG. 3), a matéria (InTerValo, 21 nov. 1965, p. 28) mostrava que o ato de "falar com o povo" fazia-se pelas imagens da TV, capas de disco e fotografias em revista, daí a importância dos olhos verdes de Chico. Com isso não se quer diminuir a importância da forma e conteúdo das canções, mas mostrar que a elas se adicionavam competências próprias 
da gramática televisual que impregnou as representações da música popular nesse momento.

A beleza, vasta cultura musical e também timidez, acabaram favorecendo Chico Buarque no programa Esta Noite se Improvisa. Televisionado pela Record, tratava-se de um duelo de memória musical. Shows como esses, já populares no rádio, ao serem televisionados, ganhavam sentido especial. Pelo programa passaram Roberto Carlos, Erasmo Carlos, Nara Leão, Elis Regina, Geraldo Vandré e Edu Lobo, mas as grandes estrelas eram Caetano Veloso, Chico Buarque e Carlos Imperial. O que tinham em comum um baiano extremamente magro com cabelos esvoaçantes, um rapaz de classe média tímido e bonito, e um gordo que xingava a plateia e andava de chinelos e blusa florida aberta? Todos não só eram exímios compositores e tinham prodigiosa memória musical, mas souberam compor uma galeria de personagens com apelo televisual. Além da beleza, Chico transformou a timidez em sinônimos de "bom mocismo". Usando a erudição para entreter o público, fortalecia o pré-requisito da "simplicidade" necessário a um ídolo de massas.

Sua fama até lhe rendeu um convite para o cinema. Enquanto os artistas da Jovem Guarda possuíam diversas participações em filmes (Juventude e Ternura, Roberto Carlos em Ritmo de Aventura, Na Onda do lê-iê-iê), Chico fez uma ponta em Garota de Ipanema, como um flerte da protagonista, típica menina da zona sul carioca. O cantor ainda promoveu o Mug (FIG. 3), o curioso boneco de pano com cabelo espetado e roupa xadrez, ao qual era atribuído o papel de amuleto da sorte; Tratava-se de uma gozação inventada pelo produtor do Fino da Bossa e do Jovem Guarda e que remetia aos artigos similares licenciados por Roberto e seus colegas.

Vandré é o terceiro personagem de destaque da música popular moderna. Ele também conheceu a consagração no II Festival da Música Popular da TV Record. A composição Disparada, que narra o processo de tomada de consciência de um boiadeiro frente à exploração, fez com que dividisse o primeiro lugar com Chico. Sua veia combativa também se expressava de outras formas. Aproveitava todas as brechas na mídia para anunciar sua suposta missão de comunicar-se com o homem do campo e lutar contra a alienação cultural. Fazia ainda graves acusações contra as empresas de comunicação que a seu ver objetivavam "a conquista pura e simples do mercado sem a menor preocupação ou responsabilidade de ordem cultural e artística" (Contigo, set. 1966, p. 22). As críticas se estendiam à TV Record, cujo interesse pela música brasileiro, segundo Vandré, só existia quando o lucro fosse garantido, como nos festivais. A declaração foi responsável pelo cancelamento de seu contrato. 
Imersos nesse regime televisual, o foco na vida íntima dos artistas da MPB era constante. Chegou-se até a cogitar um romance entre Edu Lobo e Elis Regina ou também entre a musa da Bossa Nova, Nara Leão, e o galã da Jovem Guarda, Jerry Adriani (FIG. 4). Quanto mais intangível o ídolo, mais se proliferavam as matérias que ofereciam sua intimidade como mercadoria para consumo massivo. Dialogar com o forte componente visual que então se impunha midiaticamente era condição indispensável ao sucesso. A tarefa tornou-se mais complexa com a construção de uma "guerra" entre a moderna música popular e o iê-iê-iê.

- Figura 3 - As representações midiáticas de Chico Buarque

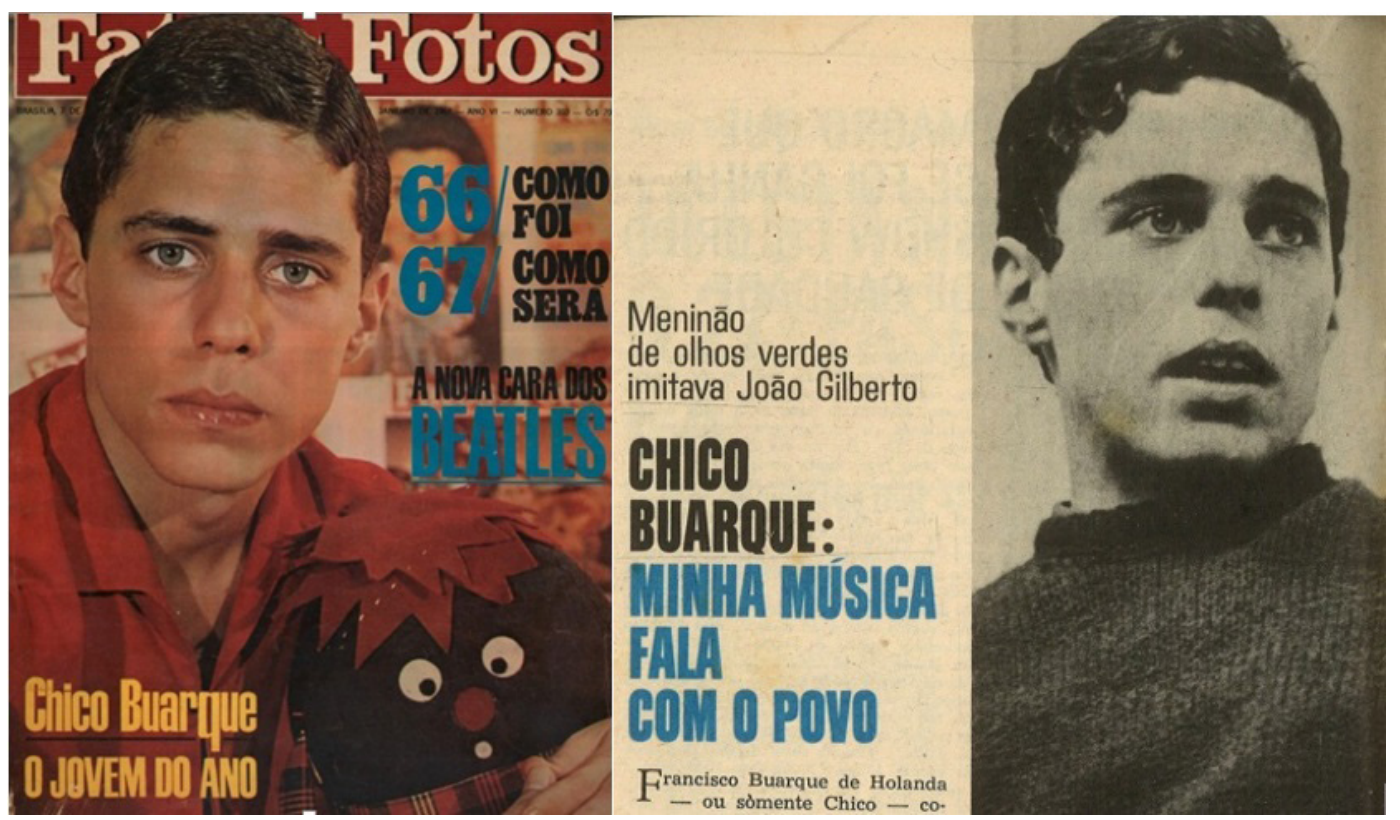

Fonte: Fatos e Fotos, jan. 1967, InTerValo, 21 nov. 1965, p.32.

Figura 4 - A vida íntima da MPB

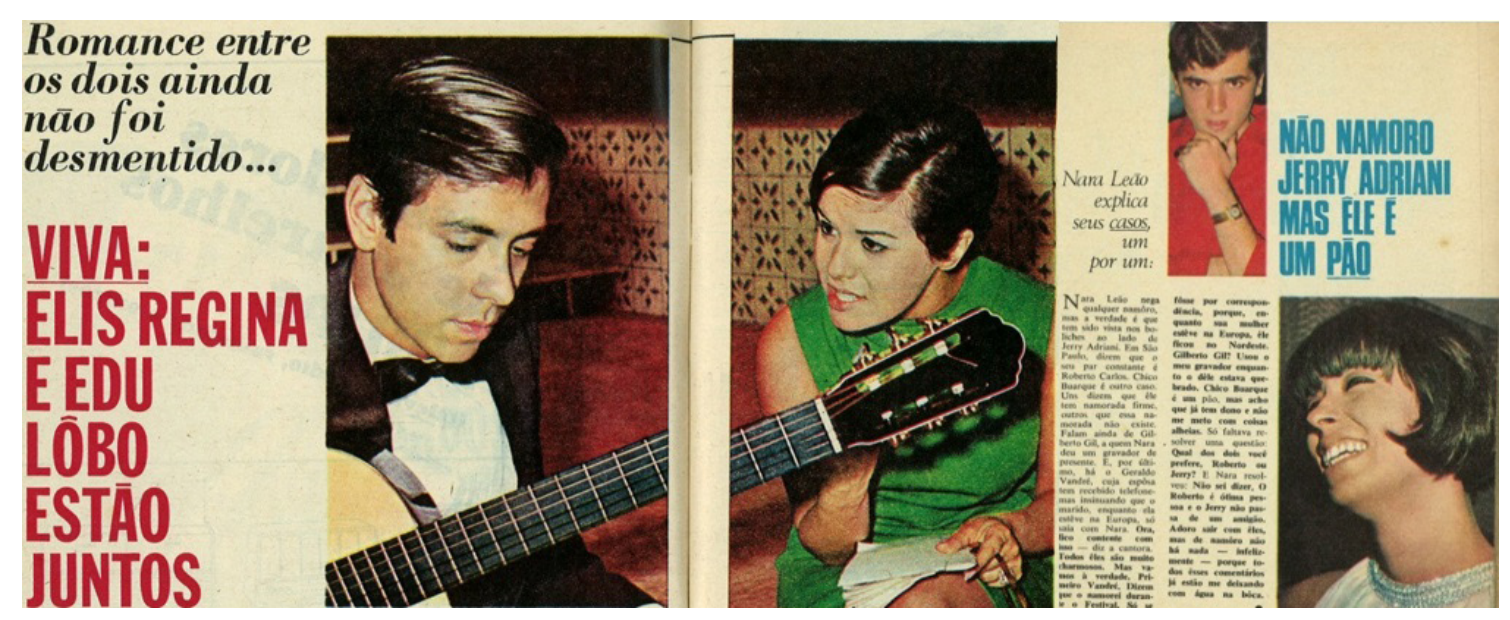

Fonte: Intervalo, 7 mai. 1967, p.13 e 19 dez. 1966, p.32 


\section{A lógica da "guerra" e seus episódios}

Semanários televisivos, como a revista InTerValo, revistas de variedade, como a Manchete e $O$ Cruzeiro, além dos informativos de música popular dos grandes jornais retratavam o mundo dos espetáculos como um universo de glamour, sonhos e fantasias onde escondiam-se paixões e conflitos de interesses que moviam os artistas ao estrelato. Instituir uma "guerra" entre duas "facções" da música popular foi uma forma de fabricar uma narrativa espetacular na qual uma batalha se seguia à outra, passível de ser consumida como uma ficção seriada, repleta de episódios emocionantes e desfechos surpreendentes.

Por conta de conflitos como os do Vietnã, o uso do vocabulário bélico impregnava a imprensa na segunda metade da década de 60 . Um exemplo curioso está no editorial $\mathrm{Na}$ Moda como na Guerra que apresentava figurinos de inspiração militar. Publicado n'O Cruzeiro, dizia: "num mundo de guerras (frias e quentes) guerrilhas e agitações, um setor não assina trégua, a moda (...). E a mulher não perde um minuto sequer na batalha do bom gosto" (O Cruzeiro, julho 1967, p. 21). Não surpreende que um dos filmes mais anunciados no jornal fosse Dr. Jivago, produção norte americana que trata de um caso de amor durante a revolução russa. Isso mostra como a simbologia militar não apontava somente para conflitos reais, mas fornecia um quadro de referências que seria instrumentalizado pela imprensa, moda, cinema ou música.

No caso que nos interessa, a noção de "guerra" constrói decisivamente a percepção das disputas de poder no campo da cultura. Disputas, eleições e concursos - como o de "Rainha do Rádio" - que há tempos compunham a espinha dorsal do cenário musical, eram agora reeditados sob novo pano ideológico. Jovem Guarda e MPB compartilhavam a mesma estrutura comercial televisiva, disputando nichos de mercado ainda indefinidos. A "guerra" era uma tentativa de separar os grupos, evidenciando, no entanto, os trânsitos, encontros e demandas que ambos os segmentos experimentavam. A partir desses pressupostos analisaremos alguns episódios destacados desse embate que nos permitem lidar com essas ambiguidades. Três deles nos interessam em particular: as ofensivas de Elis contra a Jovem Guarda, a passeata contra as guitarras elétricas e o Manifesto do iê-iê-iê contra a onda de inveja. Ao longo da narrativa reconstituiremos outros eventos secundários que possibilitam estabelecer uma lógica entre eles.

No meio da década de 60, Elis consagrou-se com Arrastão, o que lhe valeu o comando de seu próprio musical na Record. Sua performance apoteótica nos palcos era acompanhada da construção de uma persona midiática igualmente explosiva, a "Pimentinha", artista tão talentosa, quanto arredia. Tratava-se de um prato cheio para a mídia sensacionalista, o que ela alimentou através dos 
múltiplos embates com seus pares. A maneira de cantar, a atuação no palco e a performance da vida privada devem ser entendidas em sua complementaridade, como um conjunto de estratégias - não inteiramente conscientes - que a cantora acionou a fim de se distinguir em meio à gramática audiovisual dos meios. Portanto, Elis não somente foi "usada" pelas mídias, mas participou ativamente da construção de sua imagem, processo no qual a "guerra" contra a Jovem Guarda contribuiu decisivamente. Não é um acaso que os dois personagens mais notórios desse confronto fossem a Pimentinha e o Tremendão. Erasmo, e seu gênio explosivo, faziam dele um contraponto à figura introspectiva de Roberto.

O ano de 1965 encerrou-se com o sucesso do Fino da Bossa que com $24 \%$ da audiência liderava as noites de $4^{a}$ feira (Ibope, 1965). Elogiado por seu "bom gosto, tato e entusiasmo", fazia crer na renovação do samba que vinha de São Paulo (Augusto, 1965, p. 7). Ao retornar das férias em março do ano seguinte, Elis encontrou um cenário bastante diferente. Respaldado pela mídia e por um séquito de fãs que se aglomeravam no Teatro Record, Roberto Carlos era responsável pela canção mais ouvida no momento, Quero que vá Tudo pro Inferno. A reação de Elis veio por meio de um suposto bilhete afixado nos bastidores do teatro:

Atenção, pessoal, O Fino não pode cair! De sua sobrevivência depende a sobrevivência da própria música moderna brasileira. Esqueçam quaisquer rusgas pessoais, ponham de lado todas as vaidades e unam-se todos contra o inimigo comum: o iê-iê-iê (Mello, 2003, p. 145).

Na sequência, a InTerValo (1966) publicou a reportagem de capa, Jovem Guarda declara guerra à Bossa Nova, na qual Erasmo Carlos que como cantor havia vendido "50 mil discos e como compositor, 700 mil", reclamava que "cantores e diskjockeys [geralmente adeptos da Bossa Nova] se referem a ele, bem como aos demais integrantes da Jovem Guarda, como debiloides e submúsicos" (InTerValo, 6 mar. 1966, p. 4) não os convidando para seus shows.

Que grande parte dos músicos da nascente MPB nutrisse uma aversão ao rock e derivados não é novidade. Isso existia desde fins da década de 50, quando o gênero norte-americano se popularizou no Brasil, concomitantemente ao êxito da Bossa Nova (Motta, 2000). No entanto, a separação que havia entre os dois circuitos culturais era, agora, rompida. A Bossa Nova, tornada música popular moderna, encontrava-se com o rock, tornado iê-iê-iê, sob a égide da TV Record. Uma disputa por público ganhava terreno, o desafio era transformá-la em "guerra". 
Os dados do IBOPE (1966-1968) mostram que entre 1966 e 1968, Roberto Carlos e Chico Buarque lideravam a venda de discos. Tratava-se de um mercado ainda não repartido por nichos bem definidos e no qual os arraigados hábitos de consumo ainda dominavam o público. Assim, não é um acaso que as canções de maior sucesso, A Banda, de Chico, e Quero que vá tudo para o Inferno, de Roberto, estivessem ancoradas, respectivamente nas marchinhas e na tradição romântica, gêneros de apelo radiofônico massivo. A guerra, portanto, refletia não só a real disputa de mercado encenada nos meios de comunicação, mas também a disputa por legitimidade. Ao negar o rótulo de submúsico, Erasmo expressava um ressentimento em relação à crítica ilustrada e a discussão política que haviam reconfigurado os critérios de valor da música popular nos anos 60, promovendo um corte entre êxito comercial e legitimidade artística. Se o sucesso do cantor era comparável ao de Orlando Silva nas décadas anteriores, seu prestígio certamente não o era. Como resposta a Erasmo, a mesma InTerValo (1966) publicou a matéria "Elis Regina revida à ofensiva da Jovem Guarda", que continha a suposta declaração da cantora.

\footnotetext{
De volta ao Brasil, eu esperava encontrar o samba mais forte do que nunca. O que vi foi essa submúsica, essa barulheira arrastando milhares de adolescentes que começam a se interessar pela linguagem musical e são assim desencaminhados. Esse tal de iê iê iê é uma droga: deforma a mente da juventude. Veja as músicas que eles cantam: a maioria tem pouquíssimas notas e isso as torna fáceis de cantar e guardar. As letras não contêm qualquer mensagem: falam de bailes, palavras bonitinhas para o ouvido, coisas fúteis. Qualquer pessoa que se disponha pode fazer música assim, comentando a última briguinha com o namorado. Isso não é sério nem é bom. Então, por que manter a aberração? Nós, brasileiros, encontramos uma fórmula de fazer algo bem cuidado para a juventude, sem apelar para rocks, twists, baladas, mas usando próprio balanço do nosso samba (InTerValo, 27 mar. 1966, p. 10).
}

Segundo a reportagem, Elis, "aborrecidíssima com a queda de cotação da música popular brasileira" havia reassumido "seu posto no Fino", "o quartel general da bossa-nova" com o objetivo de "melhorar o gosto do público", em especial da juventude. Lembrando tratar-se da "pimentinha", a reportagem abusava do vocabulário bélico para reafirmar o comportamento explosivo da cantora, o que ficaria patente nesta curiosa imagem. 
- Figura 5 - Elis e a suposta declaração de guerra ao iê-iê-iê

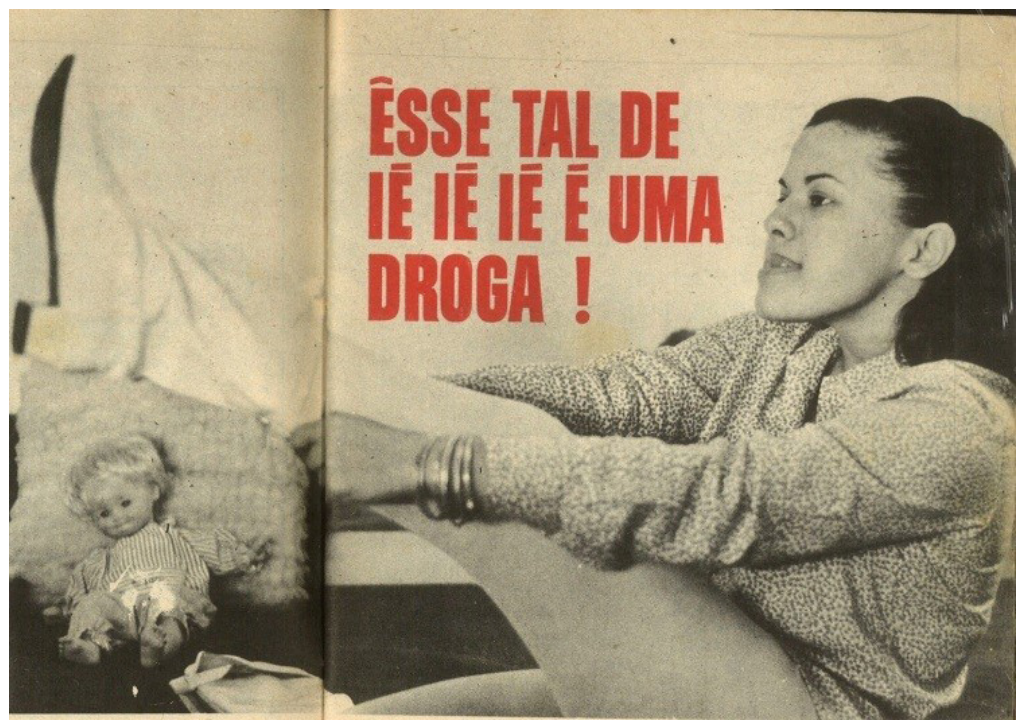

Fonte - InTerValo, 27 mar. 1966, p 10.

A declaração repercutiu nos mais diversos meios, causando um malestar tão grande que levou a cantora a manifestar-se na televisão, acusando a InTerValo de forjar intrigas. Em sua defesa, o diretor de redação, Alberto Maduar, afirmava que a revista era"um reflexo fiel do que ocorre na TV brasileira", portanto, não era necessário “jogar ninguém contra ninguém ou forjar reportagens para vender mais" (Maduar, 1966). A fim de celebrar uma trégua, a cantora participou de um "almoço da paz", com os diretores da InTerValo e um dos responsáveis pela publicidade do Jovem Guarda (InTerValo, 15 mai. 1966). Junto a Wilson Simonal, Jorge Ben e Jair Rodrigues, fez ainda uma aparição no aniversário de Roberto Carlos. O show para mais de cinco mil pessoas foi registrado pelas lentes de Luiz Sergio Person com vistas a integrar um filme de aventuras, nunca finalizado.

Episódios como esse deixam claro como a imagem de cada artista se faz na confluência entre suas trajetórias de vida e representações midiáticas, o que envolve uma batalha por representação travada no interior dos próprios meios. Assim, não interessa o quanto há de "inventado" ou "real" nessa matéria. Esse tipo de distinção pouco nos ajuda nesse momento. Ainda que a InTerValo construísse suas reportagens com fins espetaculares, é fácil notar que Elis conhecia essa lógica, utilizando-a seu favor. Se a "guerra" era midiática, a trégua também o era, portanto só fazia sentido na medida em que fosse encenada midiaticamente. Isso explica por que Elis recorre à TV para argumentar contra a mídia impressa e depois ao cinema para celebrar a paz. Isso mostra, ainda, como diferentes meios remetiam uns aos outros, revelando o caráter intertextual dessa guerra em que a dimensão visual era evidente. 
Outra centelha do conflito voltou a brilhar quando o Fino da Bossa foi cancelado em junho de 67, desencadeando a, hoje tão lembrada, "passeata das guitarras elétricas". Frente Única da Música Popular Brasileira é o nome do show que substituiria a atração extinta, conservando seu elenco. O objetivo, tal como divulgado na mídia impressa, era "unir os inimigos e vencer o iê-iê-iê", ideia, no entanto, que "não partiu dos compositores e sim da direção da TV Record" (O Estado de S. Paulo, 18 jul. 1967, p. 8). A famosa "passeata" era uma forma de promover o novo programa.

Tudo começou às seis da tarde do dia 17 de julho, em uma concentração no Largo de São Francisco com a presença de Wilson Simonal, Chico Buarque, Elis, Jair, o sambista Zé Keti, entre outros. Enquanto o assédio dos fãs impedia os dois primeiros de deixarem o interior de um carro de som que entoava músicas brasileiras, os demais ocuparam as ruas, dando as mãos e estendendo uma grande faixa com o nome do programa. Quando a carreata atingiu o Teatro Paramount, Chico e Simonal deixaram o veículo, frente à audiência que agitava bandeirinhas do Brasil cedidas pela produção. No interior do teatro, Juca Chaves juntou-se aos artistas, não só para cantar, mas também fazer piadas. Ao fim do show, plateia e cantores entoavam o "hino" da Frente Única: "Moçada querida / cantar é a pedida / cantando a canção / da Pátria querida / cantando o que é nosso com o coração" (mesmo autor).

O evento, hoje tomado como um dos símbolos máximos da "MPB engajada x Jovem Guarda alienada", não foi sequer noticiado por grande parte dos jornais e semanários na época. Um dos poucos veículos que o fizeram, descreveu o episódio não como passeata, mas como uma "festa" idealizada pelo diretor do programa, Manoel Carlos (mesmo autor). Em entrevista recente, Paulinho Machado de Carvalho, que então comandava a programação musical da emissora, faz uma reveladora declaração sobre a relevância do evento: "eu vi em vários livros, mas não me lembro muito bem, pelo que soube, foi muito pequena" (Calil; Terra, 2013). Esse relato é parte do livro Uma Noite em 67, que reúne depoimentos colhidos para o documentário homônimo sobre os Festivais da Canção. É interessante notar que a ênfase dada pelo filme à "passeata" contrasta com a pouca importância notada nos registros de época e na declaração de Paulinho, o que dá uma boa medida de como o episódio foi superdimensionado ao longo do tempo.

Um último caso, digno de nota, é o curioso Manifesto do iê-iê-iê contra a Onda de Inveja publicado na revista O Cruzeiro. Tratava-se da contraofensiva organizada pelos “integrantes Estado Maior do lêiêiê" - Roberto, Erasmo e Carlos Imperial - à Frente Única do samba: 
Fazer música que o povo não canta, não é vantagem, não queremos ganhar festivais e nem ser chamados de geniais". "somos um movimento otimista (..) Não falamos (..) de tristeza, de dor de cotovelo, de desespero, de fome, de seca, de guerra. Somos sempre uma mensagem de alegria para todo o povo (SOARES, MOTTA, 1967)

Nessa perspectiva, todo o desprezo e crítica dirigidos à Jovem Guarda resumiam-se à inveja. O "manifesto", que é fundamentalmente uma longa entrevista com Carlos Imperial, não passa de uma de suas empreitadas espetaculares. Gordo, espaçoso e extravagante, o folclórico Imperial estava sempre forjando alguma polêmica para se promover. Chegou a declarar que o "iê-iê-iê não é apenas um ritmo. É um movimento. Um movimento sério que visa conquistar um grande carango, um bom apartamento e uma namoradinha bonita" (Leonam, 1967). O cantor, compositor e apresentador de TV naquele momento era bastante conhecido por provocar vaias na plateia do Esta noite se improvisa. Poucos anos antes, fora responsável pela promoção do rock $n$ 'roll no Brasil, incentivando Roberto e Erasmo em início de carreira. Ainda nos anos 50, havia até tentado, sem sucesso, fazer de Roberto o "príncipe da Bossa Nova" (Araújo, 2006).Circulando na boêmia desde muito cedo, conhecia bem osjargões que caracterizavam o discurso engajado. A ideia de um "manifesto" e "Estado Maior" - falaria ainda de "esquerda festiva" - eram formas de instrumentalizá-lo. Por mais surpreendentes que fossem suas bravatas, elas não destoavam tanto do idioma midiático que empregava o imaginário da guerra para vender filmes, revistas e roupas, como vimos.

\section{CONSIDERAÇÕES FINAIS}

Como vimos no início do texto, a crença em uma divisão rígida entre Jovem Guarda e MPB ainda permeia a memória sobre a música popular dos anos 60 . Assim, por mais espetaculares que sejam as representações midiáticas, elas não deixam de ser reais: a realidade está em seus efeitos, em seu impacto sobre a percepção, que têm consequências diretas na posição que as práticas ocupam no espaço social. Portanto, acompanhar os episódios que constituíram a "guerra" da MPB contra a Jovem Guarda é perceber como os meios de comunicação, a TV em especial, ao categorizar os agentes em diferentes grupos e forjar uma rígida divisão entre eles tornaram-se espaços centrais para a redefinição de hierarquias na música popular. Isso, no entanto, se fez em meio a uma série de ambiguidades, trânsitos e símbolos compartilhados que revelam a impossibilidade de apreender as relações entre grupos e artistas a partir de simples dicotomias. 
Ao defender a centralidade da TV nesse processo não se quer negar a persistência do rádio que se expressou, por exemplo, no repertório romântico de Roberto e na influência de Ângela Maria no canto de Elis Regina. Lembramos ainda como outros tipos de disputa, como aquela entre Emilinha e Marlene, já existiam anteriormente. No entanto, na década de 60 o sentido político era muito distinto e lidar com o componente visual, fruto do poder da televisão, tornou-se uma condição de sucesso para os artistas emergentes.

É possível marcar o fim da guerra entre MPB e Jovem Guarda com o III Festival da Música Popular Brasileira da TV Record que contou com a participação de Erasmo, com Capoeirada, e Roberto, com Maria, Carnaval e Cinzas. Apesar de afinadas às temáticas engajadas dos festivais, as canções não salvaram seus intérpretes de vaias. No entanto, esse movimento voltava a reafirmar as possibilidades de trânsito entre MPB e Jovem Guarda que a "guerra" havia nublado. O ponto alto do evento foi a apresentação eletrificada de Gilberto Gil e Caetano Veloso, que anunciavam a chegada do Tropicalismo e de novos embates com amplas repercussões midiáticas. Ocupando, também, a televisão, revistas de variedades e semanários televisivos, formava-se uma nova guerra: tropicalistas versus a "linha dura do samba". Permanecia a lógica, mudavam os personagens.

\section{REFERÊNCIAS}

AUGUSTO, Sergio, Panorama, Jornal do Brasil, 19 ago. 1965, p. 7.

ARAUJO, Paulo César de. Roberto Carlos em detalhes. Rio de Janeiro: Editora Planeta, 2006.

BOURDIEU, Pierre. Espaço social e poder simbólico. In: Coisas ditas. São Paulo: Brasiliense, 1990.

A economia das trocas linguísticas: o que falar quer dizer. São Paulo: EDUSP, 1996.

CALIL, Ricardo.TERRA, Renato. Uma noite em 67. São Paulo: Planeta, 2013.

CARLOS, Erasmo. Minha Fama de mau. Rio de Janeiro: Objetiva, 2009.

CONTIGO (revista). CHICO BUARQUE: o arquiteto do samba, set. 1966, p. 31-33.

FRENTE ÚNICA lotou teatro. O Estado de S. Paulo, 18 jul. 1967, p. 8.

GHEZZI, Daniela Ribas. Música em Transe: O momento crítico da emergência da MPB (1958-68). Tese de Doutorado, IFCH/UNICAMP, Campinas, 2011. 
HALL, Stuart. Representation. Cultural representation and signifying practices. Londres: Sage, 1997.

IBOPE, Boletim de Assistência de TV de São Paulo. São Paulo. Arquivo Edgar Leuenroth, IFCH/ Unicamp, 1965.

IBOPE, Pesquisa de venda de discos de São Paulo. Arquivo Edgar Leuenroth, IFCH/ Unicamp, 1966-1968.

InTerValo (revista). Intervalo recebeu Elis Regina no almoço de paz, 15 mai. 1966, p.18-19.

InTerValo (revista). Bonitão tamanho família, 27 nov. 1966, p. 18-19.

InTerValo (revista). CHICO BUARQUE: Minha música fala com o povo, 21 nov. 1965, p. 28-29.

InTerValo (revista). "ESSE TAL de iê-iê-iê é uma droga" Elis Regina reage à ofensiva da Jovem Guarda, 27 mar. 1966, p. 10-11.

InTerValo (revista). Jovem Guarda declara guerra à bossa nova, 6 mar. 1966, p. 4.

InTerValo (revista). Roberto, meu filho, 8 maio 1966, p. 3-5.

IVO, Ledo. Chico Buarque: O Nôvo poeta do povo, Manchete, 22 out. 1966, p.106-107.

LEONAM, Carlos. Carioca quase sempre, Pra ter fom fom, trabalhei, trabalhei: a receita do sucesso, Jornal do Brasil, 16 jun. 1967, p. 7.

MANCHETE (revista). CHICO BUARQUE: O general da banda, 29 out. 1966, p. 14-15.

McDONELL, Andrea Marie. Just Like Us: Celebrity Gossip Magazines in American Popular Culture. 2012. 140 f. Tese (Doutorado em Comunicação). Universidade de Michigan, Michigan, 2012.

MELLO, Zuza Homem de. A era dos festivais. Uma parabóla. São Paulo: Editora 34, 2003.

MOTTA, Nelson. Noites Tropicais. São Paulo: Objetiva, 2000.

NA MODA como na guerra. O Cruzeiro, julho 1967, p. 21-25.

NAPOLITANO, Marcos. Seguindo a canção: Engajamento político e Indústria Cultural na MPB (1959-1969). (versão revisada pelo autor). São Paulo: Anna Blume/ FAPESP, 2010.

. A MPB na era da TV. In: SACRAMENTO, Igor; RIBEIRO, Ana Paula Goulart; ROXO. História da televisão no Brasil: do início aos dias de hoje. São Paulo: Contexto, 2011. p. 85-105. 
NAVES, Santuza Cambraia. Canção popular no Brasil. Rio de Janeiro: Civilização Brasileira, 2010.

PAIANO, Enor. 0 berimbau e o som universal. Lutas culturais e indústria fonográfica nos anos 60. Dissertação (Mestrado em Comunicação Social) -, ECA/USP, São Paulo, 1994.

PEDERIVA, Ana Barbara Aparecida. Jovem Guarda: cronistas sentimentais da juventude. São Paulo: Companhia Editora Nacional, 2000.

PITANGA, Camila. Som Brasil. Especial Jovem Guarda. TV Globo, 26 maio 2012.

SOARES, AFRANIO; MOTTA, Manoel. Manifesto do iêiêiê contra a onda de inveja. $\mathbf{0}$ Cruzeiro, 5 ago.1967, p. 4-9.

TINÉ, Flavio. O compositor: esse desconhecido. Contigo, set. 1966, p. 22-23

VASCONCELOS, ARY. As duas Wanderléias, Manchete, 22 jan. 1966, p. 58-61.

ZIMMERMANN, Maíra. Jovem Guarda: moda, música e juventude. São Paulo: Estação das Letras e Cores, 2013.

ZAN, José Roberto. Do Fundo de Quintal à Vanguarda: contribuição para uma História Social da música popular brasileira. Tese (Doutorado), IFCH/UNICAMP, Campinas, SP, 1997.

Recebido em: 18/01/2018

Aceito em: 07/04/2018

Dados do autor:

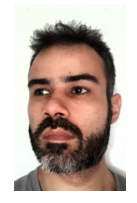

Marcelo Garson | garson.marcelo@gmail.com

Universidade Federal de Juiz de Fora (UFJF)

Doutor em Sociologia pela Universidade de São Paulo (USP). Realiza pós-Doutorado em Sociologia, como

bolsista da CAPES, pela Universidade Federal de Juiz de Fora (UFJF).

Endereço do autor:

Programa de Pós-Graduação em Ciências Sociais da Universidade Federal de Juiz de Fora (PPGCSO-UFJF)

Prédio Novo do ICH - Sala A-III-01-H

Campus Universitário - Martelos

36.036-330 - Juiz de Fora/MG 